\title{
Studi Etnobotani Dioscorea spp. (Dioscoreaceae) dan Kearifan Budaya Lokal Masyarakat di Sekitar Hutan Wonosadi Gunung Kidul Yogyakarta
}

\author{
Purnomo $^{\left.1^{*}\right)}$, Budi Setiadi Daryono $^{1)}$, Rugayah $^{2)}$, dan Issirep Sumardi ${ }^{1)}$ \\ ${ }^{1)}$ Fakultas Biologi, Universitas Gadjah Mada, Yogyakarta 55281 \\ ${ }^{2}$ Divisi Botani, Pusat Penelitian Biologi, LIPI, Cibinong 16911
}

Diterima 15-12-2011Ｄisetujui 19-07-2012

\begin{abstract}
Dioscorea spp. were cultivated as alternative food in the garden and yard on dry season, and it's planted by peoples in the villages. The objectives of the research are to identify the species, the tuber use, and the local wisdom to support the conservation of Dioscorea around Wonosadi forest. Samples and data collection was conducted in 15 villages around Wonosadi forest. Interview survey was done on peoples who are cultivate yam species (Dioscorea spp.) in their garden. Research were emphasized to tuber characteristic, traditional uses, and local wisdom to supporting yam conservation. Data was analyzed descriptively to illustrate the kind of local usage and local wisdom of connect with Dioscorea spp. The results showed that there were found species of gembili (D. esculenta (Lour.) Burk.), uwi (D. alata L.), and gadung (D. hispida dennst.) as cultivated plants, and tomboreso (D. pentaphylla L.), gembolo (D. bulbifera L.), and jebubuk (D. numularia Lamk.) as wild species in the forest. Tuber is raw material for many kind of food based on carbohydrate content. Gadung were used as fickle food with high diversification and insecticide for rice and corn. Peoples more consume gembili and $u w i$ than gembolo and others species as rice substitute at dry season. The local wisdom were indicated that peoples still consume gembili and uwi as rice substitute, while tuber also used as sesaji in traditional concept jajan pasar or tukon pasar, and tuber of uwi was used as diet for diabetes complaint, and row material of uwi ungu tuber was used effectively for diarrhea complaint in the villages.
\end{abstract}

Keywords: Dioscorea spp., ethnobotany, local wisdom, Wonosadi forest, Yogyakarta

\begin{abstract}
ABSTRAK
Dioscorea spp. adalah tanaman pangan alternatif di halaman dan kebun pada musim kering, dan ditanam oleh masyarakat di pedesaan. Tujuan penelitian adalah mengidentifikasi spesies, manfaat umbi, dan kearifan lokal yang mendukung pelestarian Dioscorea spp. di sekitar hutan Wonosadi, Gunung Kidul, Yogyakarta. Koleksi sampel dan data dilakukan pada 15 desa di sekitar hutan Wonosadi. Survei interview dilakukan pada masyarakat yang menanam Dioscorea spp. di kebun atau halaman rumah, dan dititikberatkan beratkan pada karakter khas umbi, pemanfaatan tradisional, dan kearifan budaya masyarakat yang mendukung pelestarian Dioscorea spp. Data dianalisis secara deskriptif untuk menggambarkan karakter khas spesies Dioscorea, pemanfaatan tradisional, dan bentuk kearifan budaya masyarakat terkait dengan tanaman Dioscorea spp. Hasil penelitian menunjukkan bahwa ditemukan spesies gembili (D. esculenta (Lour.) Burk.), uwi (D. alata L.), dan gadung (D. hispida dennst.) sebagai tanaman budidaya dan Tomboreso (D. pentaphylla L.), gembolo (D. bulbifera L.), dan jebubuk (D. numularia Lamk.) sebagai spesies liar di hutan. Umbi merupakan bahan dasar berbagai macam makanan berbasis karbohidrat. Gadung dimanfaatkan untuk ceriping juga insektisida bagi padi dan jagung. Masyarakat lebih mengkonsumsi umbi gembili dan uwi daripada gembolo dan jenis lainnya sebagai pengganti beras di musim kering. Kearifan lokal ditunjukan dengan masih mengkonsumsi umbi gembili dan uwi sebagai cadangan pangan di musim kering, demikian juga menggunakan umbi Dioscorea spp untuk sesaji dalam konsep jajan pasar atau tukon pasar, dan umbi uwi juga dimanfaatkan untuk diet bagi penderita kencing manis, dan bahan mentah umbi uwi ungu untuk mengatasi diare di pedesaan.
\end{abstract}

Kata Kunci: Dioscorea spp., etnobotani, kearifan lokal, hutan Wonosadi, Yogyakarta

\footnotetext{
*Telp: +628156858078

Email: pakkencur@yahoo.com
} 


\section{PENDAHULUAN}

Wilayah ekosistem karst tersusun atas batuan kapur memiliki karakter top soil tipis, berpori sehingga air cepat meresap, dan memiliki goa yang terbentuk karena kelarutan kalsium batuan. Pegunungan kapur di Gunung Kidul, Yogyakarta adalah ekosistem karst, merupakan karst berjenis tanah lempung ketinggian tempat 90-800 $\mathrm{m}$ di atas permukaan laut (m.dpl.) dengan musim hujan 4-5 bulan. Sungai bawah tanah dan cekungan merupakan sumber air minum dan irigasi. Vegetasi wilayah tersebut akan tumbuh dan berkembang pada musim hujan dan kering, beberapa spesies tumbuhan mengalami kematian secara alamiah, kecuali beberapa spesies yang tahan kering.

Budaya penduduk berkaitan dengan pekarangan disebut karang-kitri dari kata karang (batu karang atau pekarangan) dan kitri adalah tetuwuhan (Jawa) atau tumbuhan, diartikan penduduk sangat efektif dalam memberdayakan pekarangan dengan tanaman pangan yang dapat menyangga kebutuhan hidupnya pada saat musim kering atau paceklik (masa tunggu antara musim tanam dan panen tanaman pokok). Pada musim tersebut, masyarakat mengandalkan mata pencaharian sebagai peternak atau buruh di daerah sekitarnya, karena pada musim ini sangat sulit didapatkan air untuk irigasi pertanian. Pada umumnya masyarakat pedesaan telah mengenal berbagai jenis tanaman penghasil umbi, dan mengkonsumsi berbagai jenis umbi untuk makanan sehari-hari atau untuk ketahanan pangan di musim kering. Walaupun demikian pada kenyataannya, keberadaan beberapa spesies tanaman penghasil umbi, tidak mendapat perhatian yang memadai untuk kelestariannya (Achmady \& Schneider 1995; Frankel et al. 1995; Purnomo 2009).

Sumbangan keragaman tumbuhan di dalam ekosistem cukup besar, dan memberi dukungan pada kebutuhan hidup manusia (Arnold \& Perez 1998). Tanaman non-kayu dan kayu seharusnya memiliki perbandingan yang hampir seimbang dalam konservasi hayati (de Jong \& Utama 1998). Tanaman yang dimanfaatkan oleh masyarakat di sekitar hutan disyaratkan memiliki perhitungan waktu panen dan nilai ekonomi di pasar tradisional (Anderson 1998). Sehingga, pendataan tumbuhan dan manfaatnya penting dalam konservasi in situ dan ex situ (Rifai 1998; Waluyo et al. 2007).

Budaya masyarakat untuk mensiasati musim kering yang cukup panjang, salah satunya adalah menciptakan kearifan lokal (local wisdom) tertentu sebagai ekonomi lingkungan yang menguntungkan bagi kelangsungan hidup, mengacu pada tanaman yang dapat langsung atau tidak langsung dimanfaatkan dalam ekosistem (Martin 1995; Cotton 1995). Penduduk lokal memiliki tata cara pengenalan dan klasifikasi tradisional yang memudahkan dalam pemanfaatan tumbuhan, misalnya polo gemantung misalnya waluh (Cucurbita moschata L.), polo kesimpar misalnya kacang tanah (Arachis hypogaea L.), dan polo kependem misalnya Dioscorea spp. (Tjitrosoepomo 1980; Waluyo et al. 2007).

Spesies Dioscorea sebagian besar menghasilkan umbi, yang dapat dimanfaatkan untuk makanan atau obat-obatan tradisional. Umbi mengandung karbohidrat dalam jumlah yang cukup besar, dapat menjadi bahan dasar pembuatan tepung atau etanol (alkohol). Tanaman gadung (Dioscorea hispida) umbinya mengandung diosgenine bersifat racun (Bimantoro 1981; Bressan et al. 2007). Dioscorea spp. merupakan tanaman semusim dengan batang membelit, dan membentuk umbi sebagai makanan alamiah babi hutan dan kerabat dekatnya (Achmady \& Schneider 1995; Maneenoon et al. 2008). Umbi oleh manusia dapat diolah menjadi makanan, minuman isotonik, dan alkohol (Ariesta 2004). Tanaman Dioscorea spp. memiliki keunggulan dibandingkan dengan tanaman umbi-umbian yang lain karena mudah tumbuh di daerah kritis tanpa perawatan yang berarti.

Hutan Wonosadi di Desa Beji, Ngawen, Gunung Kidul adalah hutan yang diciptakan oleh masyarakat bertujuan untuk mendapatkan sumber air. Simbol kekeramatan mulai diciptakan untuk menjaga keutuhan ekosistem yang terbentuk, dengan mitos dan tahayul sebagai perspektif lokal dalam ritual etnobotani (Martin 1995). Hal semacam ini dilakukan juga oleh masyarakat Kabupaten Pacitan Jawa Timur untuk konservasi air tanah, konsep kearifan lokal dengan pengkeramatan hutan, bertujuan mendapatkan sumber air baik untuk kebutuhan rumah tangga maupun pertanian (Bapeda Pacitan 2005). Tujuan penelitian adalah untuk mengidentifikasi jenis-jenis Dioscorea di pemukiman masyarakat di sekitar hutan, mengetahui manfaat umbi Dioscorea secara tradisional, dan mengetahui kearifan lokal yang mendukung pelestarian spesies Dioscorea di hutan dan pemukiman masyarakat sekitar hutan Wonosadi, Beji, Ngawen, Gunung Kidul, Yogyakarta. 


\section{BAHAN DAN METODE}

Bahan penelitian adalah tanaman Dioscorea spp. yang ditanam di pemukiman penduduk di sekitar hutan Wonosadi dan wilayah lainnya di Gunung Kidul, Yogyakarta. Koleksi sampel dilakukan di berbagai lokasi di wilayah karst Patuk, Gedang sari, Paliyan, dan Ngawen. Dilakukan pengambilan sampel berupa batang, daun, dan umbi untuk identifikasi spesies serta kultivar setiap spesies Dioscorea. Dilakukan pengambilan gambar produk pangan olahan berbahan dasar umbi tanaman Dioscorea spp. Alat yang digunakan meliputi alat untuk wawancara berupa kuesioner dan alat untuk koleksi sampel berupa kantong plastik, kertas label, alat tulis, dan fotografi.

Identifikasi Dioscorea spp. Identifikasi spesies Dioscorea dilakukan dengan panduan kunci identifikasi dan gambar (Backer and Bakhuizen van den Brink 1968; Purnomo, et al. 2008; Sastrapradja 1977; Sastrapradja dan Rifai 1989).

Pencatatan Data. Berdasarkan survei wawancara dari 25 responden sebagai petani yang menanam tanaman uwi di rumah dan mewakili 15 Dusun dari 6 Desa di sekitar hutan Wonosadi. Berdasarkan pada kuesioner terstruktur wawancara ditekankan pada kaitan antara sifat khas umbi dan pemanfaatan lokal (Waluyo 2004). Pencatatan data dilakukan antara lain nama lokal, manfaat umbi untuk pangan, diversifikasi pangan dari umbi, kelanjutan usaha, yang paling digemari oleh masyarakat, dan manfaat umbi non pangan. Dilakukan penentuan dan pencatatan data lapangan tanaman Dioscorea spp. antara lain nama species dan nilai kekerapan setiap spesies Dioscorea di hutan Wonosadi dan di pemukiman sekitar hutan Wonosadi, Gunung Kidul, Yogyakarta. Nilai kekerapan diperhitungkan berdasarkan jumlah pekarangan penduduk yang menanam Dioscorea spp. dibagi dengan jumlah total pekarangan yang disurvey.

Analisis Data. Data dianalisis secara deskriptif dengan bantuan tabel untuk menggambarkan ragam spesies tanaman, ragam pemanfaatan dan kearifan lokal penduduk atau masyarakat dalam melestarikan tanaman Dioscorea spp.

\section{HASIL DAN PEMBAHASAN}

Spesies Dioscorea dan Sifat khas Morfologi. Berdasarkan hasil identifikasi 33 sampel Dioscorea spp. diperoleh data identifikasi mengenai nama spesies, kultivar, dan pemanfaatan tradisional (Tabel 1).

Informasi Diversifikasi Pangan dan Manfaat Lain Non-Pangan Dioscorea spp.. Dari bahan dasar umbi berbagai spesies Dioscorea di Yogyakarta memiliki kemungkinan untuk dimanfaatkan sebagai bahan diversifikasi pangan, industri, dan obat-obatan (Tabel 2).

Selain umbi gadung, masyarakat pedesaan menggunakan umbi beberapa spesies Dioscorea untuk mengatasi luka bakar (anti-imflammatory), dengan cara menempeli luka dengan parutan umbi. Hasil penelitian Olayemi and Ajaiyeoba (2007) menyatakan bahwa parutan umbi beberapa spesies Dioscorea yang tidak beracun dapat digunakan untuk obat luka bakar.

Masyarakat pedesaan mengkonsumsi umbi Dioscorea spp. dengan cara direbus sehingga nilai gizinya kurang, sebagian penduduk mengolah dengan menambahkan gula dan santan kelapa untuk menambah rasa dan gizi umbi. Penelitian Panneerselvam dan Jaleel (2008) menyatakan bahwa untuk menambah nilai gizi tepung umbi dapat disimpan dengan mencampurkan gula.

Perbandingan nilai nutrisi antara Dioscorea spp. dengan umbi keladi (Colocasia esculenta (L). Schott) dan kentang (Solanum tuberosum L.) dilakukan oleh Maneenoon et al. (2008) hasilnya menunjukkan bahwa nilai nutrisi Dioscorea spp. setara dengan $C$. esculenta dapat sebagai pengganti kentang.

Umbi gadung diketahui beracun, sehingga memerlukan pengolahan yang cermat untuk melarutkan asam sianida (HCN) yang dikandungnya, menjadi makanan siap saji (Bhandari \& Kawabata 2005). Secara tradisional HCN dapat dihilangkan dengan dicuci pada air mengalir dalam waktu tertentu, atau dilumuri dengan abu dari kayu bakar atau sampah dedaunan (pengetahuan masyarakat di sekitar hutan Wonosadi). Masyarakat menggunakan umbi gadung untuk insektisida tradisional, yaitu perasan umbi yang dicampurkan dengan perasan daun tembakau (Nicotiana tabaccum L.) untuk insektisida alami tanaman padi dan jagung.

Umbi uwi yang tersembul di atas permukaan tanah pada umumnya rasanya pahit, sehingga penduduk selalu menimbun umbi dengan tanah dan sampah daun. Komponen pahit diidentifikasi sebagai furanoid norditerpenes (diosbulbins A and B) ditemukan dengan kisaran antara 0,023-0,046 dan 0,151-0,442 g Kg-1 (Bhandari \& Kawabata 2005). Pada masa sebelum adanya pemerataan pelayanan kesehatan oleh pemerintah, masyarakat di sekitar hutan Wonosadi menggunakan umbi uwi ungu untuk mengatasi keluhan awal diare, yaitu dengan memakan umbi mentah secara langsung.

Umbi gembili dapat dikonsumsi langsung dengan rebusan, tetapi kadang-kadang menimbulkan rasa gatal 
Tabel 1 Identfikasi Dioscorea spp., karakter morfologi, dan pemanfaatan tradisional secara umum

\begin{tabular}{|c|c|c|c|c|c|}
\hline No. & Nama spesies & Nama lokal & Ciri Morfologi & Keragaman & Pemanfaatan Tradisional \\
\hline 1. & $\begin{array}{l}\text { Dioscorea hispida } \\
\text { Dennst } \\
\text { Sinonim: } \\
\text { D. daemona Roxb }\end{array}$ & \begin{tabular}{lrr} 
Gadung & \multicolumn{2}{c}{ (Jawa.), } \\
sekapa, bitule, bati \\
(Sunda), bitter yam \\
(Ing.)
\end{tabular} & $\begin{array}{l}\text { Batang gilik membelit } \\
\text { kekiri, daun majemuk } \\
\text { menjari berdaun tiga, } \\
\text { helaian tidak simetri, bulat } \\
\text { telur terbalik (ujung), bulat } \\
\text { telur (samping) } \\
\text { permukaan kasap, getah } \\
\text { daging umbi beracun. }\end{array}$ & Tidak beragam & $\begin{array}{l}\text { Umbi dapat sebagai } \\
\text { pengganti jagung dan sagu, } \\
\text { racun binatang, obat luka, } \\
\text { insektisida, bunga dapat } \\
\text { sebagai pewangi pakaian dan } \\
\text { hiasan rambut. }\end{array}$ \\
\hline 2. & Dioscorea alata $\mathrm{L}$. & $\begin{array}{l}\text { Uwi (Jawa.), huwi } \\
\text { (Sunda), water Yam, } \\
\text { Greater Yam (Ing.). }\end{array}$ & $\begin{array}{l}\text { Batang bersayap membelit } \\
\text { kekanan, daun tunggal } \\
\text { berhadapan, helaian daun } \\
\text { berbentuk anak panah, } \\
\text { bentuk dan warna umbi } \\
\text { bervariasi, membentuk } \\
\text { umbi batang (aerial tuber) }\end{array}$ & $\begin{array}{l}\text { Uwi: Beras, } \\
\text { Uwi Beras legi, } \\
\text { Uwi Beras butun, } \\
\text { Uwi Bangkulit, } \\
\text { Uwi Ungu } \\
\text { (senggani), } \\
\text { Uwi Luyung putih, } \\
\text { Uwi Luyung kuning, } \\
\text { Uwi Luyung ungu, } \\
\text { Uwi Ulo, } \\
\text { Uwi Jingking } \\
\text { Uwi Kuning, } \\
\text { Ubi Banggai } \\
\text { Uwi jingga, } \\
\text { Uwi hitam }\end{array}$ & $\begin{array}{l}\text { Umbi dapat sebagai } \\
\text { pengganti beras, dapat } \\
\text { difermentasi menjadi alkohol } \\
\text { (etanol), merupakan sumber } \\
\text { karbohidrat, warna ungu, } \\
\text { ungu muda, dan kuning dapat } \\
\text { sebagai pewarna makanan. }\end{array}$ \\
\hline 3. & $\begin{array}{l}\text { Dioscorea esculenta } \\
\text { (Lour.) Burk. } \\
\text { Sinonim.: } \\
\text { D. aculeata Auct. Non } \\
\text { L. }\end{array}$ & $\begin{array}{l}\text { Gembili (Jawa), ubi } \\
\text { aung, ubi jae, huwi } \\
\text { butul (Sunda), Lasser } \\
\text { yam (Ing.), }\end{array}$ & $\begin{array}{l}\text { Batang gilik, membelit ke } \\
\text { kiri, berduri kait daun } \\
\text { tunggal, bangun jantung, } \\
\text { umbi terbentuk di setiap } \\
\text { cabang akar, bentuk dan } \\
\text { warna umbi bervariasi, } \\
\text { tidak membentuk umbi } \\
\text { batang }\end{array}$ & $\begin{array}{l}\text { Gembili ketan, } \\
\text { gembili wulung, } \\
\text { gembili putih, } \\
\text { gembili pelus, } \\
\text { gembili jewot }\end{array}$ & $\begin{array}{l}\text { Umbi rebus enak dimakan, } \\
\text { seperti beras ketan (lekat), } \\
\text { umbi mentah berkhasiat obat, } \\
\text { umbi merupakan sumber } \\
\text { karbohidrat. }\end{array}$ \\
\hline 4. & $\begin{array}{l}\text { D. bulbifera } \mathrm{L} \text {. } \\
\text { Sinonim.: } \\
\text { D. sativa Auct. non L. }\end{array}$ & $\begin{array}{l}\text { Gembolo, jebubuk } \\
\text { basu, jebubuk endog } \\
\text { (Jawa), huwi buah, } \\
\text { huwi blicik (Sunda), } \\
\text { Aerial yam (Ing.), }\end{array}$ & $\begin{array}{l}\text { Batang gilik, berduri kait, } \\
\text { membelit ke kiri, daun } \\
\text { tunggal, bangun jantung, } \\
\text { membentuk umbi gantung } \\
\text { (bulbil) di setiap buku } \\
\text { batang, umbi membulat } \\
\text { bercabang }\end{array}$ & Tidak beragam & $\begin{array}{l}\text { Umbi gantung lebih enak } \\
\text { dibanding umbi (agak pahit), } \\
\text { umbi gantung berkhasiat } \\
\text { obat, umbi sumber } \\
\text { karbohidrat }\end{array}$ \\
\hline 5. & $\begin{array}{l}\text { D. pentaphylla } \mathrm{L} . \\
\text { Sinonim: } \\
\text { D. blumei Prain \& Burkil }\end{array}$ & $\begin{array}{l}\text { Tomboreso (Jawa), } \\
\text { uwi sawut, huwi } \\
\text { dewata, huwi mantra, } \\
\text { huwi putri (Sunda), } \\
\text { Uwi pasir, uwi sunda } \\
\text { (Jakarta), five leaf yam } \\
\text { (Ing.) }\end{array}$ & $\begin{array}{l}\text { Batang gilik, berduri kait, } \\
\text { daun majemuk menjari, } \\
\text { membentuk umbi gantung } \\
\text { di setiap buku batang, } \\
\text { umbi membulat bercabang }\end{array}$ & $\begin{array}{l}\text { Dijumpai tipe umbi } \\
\text { putih kekuningan } \\
\text { dan kuning }\end{array}$ & $\begin{array}{l}\text { Umbi adalah sumber } \\
\text { karbohidrat, dapat sebagai } \\
\text { pengganti jagung dan sagu. } \\
\text { Sebelum dikonsumsi umbi } \\
\text { diolah terdahulu untuk } \\
\text { menetralkan asam sianida. }\end{array}$ \\
\hline 6. & $\begin{array}{l}\text { D. numularia Lamk. } \\
\text { Sinonim: } \\
\text { D. oppositifolia Auct. } \\
\text { non L.; } \\
\text { D. madiunensis Prain \& } \\
\text { Burkil }\end{array}$ & Jebubuk atau Jebuk & $\begin{array}{l}\text { Batang gilik, berduri kait, } \\
\text { membelit ke kiri, } \\
\text { membentuk umbi batang, } \\
\text { daun tunggal, bulat } \\
\text { memanjang, umbi silindris } \\
\text { seperti rimpang }\end{array}$ & Tidak beragam & $\begin{array}{l}\text { Umbi tidak enak dimakan, } \\
\text { keras dan pahit rasanya. }\end{array}$ \\
\hline
\end{tabular}

waktu dimakan. Rasa gatal adalah akibat dari kandungan oksalat yang tinggi dalam umbi (Bhandari \& Kawabata 2005). Umbi gembili umum dikonsumsi oleh masyarakat Gunung Kidul, ternyata nilai gizinya baik untuk diet karena mengandung sukrosa, glukosa, fruktosa, maltosa, dan amilopektin (Panneerselvam \& Abdul Jaleel 2008). Di era tahun 1960-1970 getah (duh) umbi gembili sering digunakan untuk lem pada pembuatan layang-layang, karena getahnya sangat liat dan kuat. Menurut Ukpabi (2010) komposit tepung umbi gembili dengan rasio 80:20 b/b dapat dipakai untuk membuat roti sebaik tepung gandum di Nigeria.

Umbi gembolo jarang dikonsumsi oleh masyarakat, di era tahun 1960-1970 justru umbi gantung (Aerial tuber; jebubuk, katak) dikonsumsi untuk sarapan anak sekolah. Menurut Terauchi et al. (1991) umbi udara (bulbil) gembolo lebih banyak dikonsumsi dari pada umbi yang terdapat di dalam tanah di Asia dan Afrika. Bahkan di Rajasthan, India, gembolo merupakan salah satu komponen ramuan obat pada keluhan pernafasan seperti batuk, demam, tuberculosis, dan 
Tabel 2 Kemungkinan pemanfaatan umbi Dioscorea spp. di Yogyakarta

\begin{tabular}{|c|c|c|c|c|c|c|c|c|c|}
\hline $\begin{array}{l}\text { Umbi dari } \\
\text { species }\end{array}$ & $\begin{array}{l}\text { Pengganti } \\
\text { makanan } \\
\text { pokok }\end{array}$ & $\begin{array}{l}\text { Makanan } \\
\text { olahan }\end{array}$ & $\begin{array}{l}\text { Sumber } \\
\text { Pati }\end{array}$ & $\begin{array}{l}\text { Bahan } \\
\text { perekat } \\
\text { (lem) }\end{array}$ & $\begin{array}{l}\text { Pewarna } \\
\text { makanan }\end{array}$ & Alkohol & $\begin{array}{c}\text { Obat } \\
\text { serangga }\end{array}$ & Obat luka & $\begin{array}{c}\text { Obat luka } \\
\text { bakar }\end{array}$ \\
\hline Gadung & $\begin{array}{l}\text { Jagung } \\
\text { dan sagu }\end{array}$ & $\begin{array}{l}\text { Criping } \\
\text { Rebusan }\end{array}$ & $\begin{array}{l}\text { Ya, dengan } \\
\text { penanganan } \\
\text { racun }\end{array}$ & Tidak & Tidak & $\begin{array}{l}\text { Ya, tetapi } \\
\text { penangan } \\
\text { an racun } \\
\text { harus } \\
\text { cermat }\end{array}$ & $\begin{array}{l}\text { Insektisida } \\
\text { alami }\end{array}$ & $\begin{array}{l}\text { Ya, Luka } \\
\text { baru atau } \\
\text { Infeksi }\end{array}$ & Tidak \\
\hline Uwi & Beras & $\begin{array}{l}\text { Criping, } \\
\text { Gethuk, } \\
\text { Rebusan }\end{array}$ & Ya & Tidak & $\begin{array}{l}\text { Ya, beberapa } \\
\text { varietas } \\
\text { bewarna } \\
\text { ungu, ungu } \\
\text { muda, dan } \\
\text { kuning }\end{array}$ & $\mathrm{Ya}$ & Tidak & Tidak & $\begin{array}{l}\text { Ya, getah } \\
\text { umbi }\end{array}$ \\
\hline Gembili & $\begin{array}{l}\text { Jagung } \\
\text { dan sagu }\end{array}$ & $\begin{array}{l}\text { Criping } \\
\text { Gethuk, } \\
\text { Rebusan }\end{array}$ & Ya & $\begin{array}{l}\text { Ya, adanya } \\
\text { getah yang } \\
\text { lekat }\end{array}$ & $\begin{array}{l}\text { Ya, kultivar } \\
\text { gembili } \\
\text { wulung } \\
\text { memiliki } \\
\text { warna ungu } \\
\text { muda }\end{array}$ & $\mathrm{Ya}$ & Tidak & Tidak & $\begin{array}{l}\text { Ya, getah } \\
\text { umbi }\end{array}$ \\
\hline Gebolo & $\begin{array}{l}\text { Jagung } \\
\text { dan sagu }\end{array}$ & $\begin{array}{l}\text { Criping } \\
\text { Gethuk, } \\
\text { Rebusan }\end{array}$ & Ya & $\begin{array}{l}\text { Ya, adanya } \\
\text { getah yang } \\
\text { lekat }\end{array}$ & Tidak & $\mathrm{Ya}$ & Tidak & $\mathrm{Ya}$ & $\begin{array}{l}\text { Ya, getah } \\
\text { umbi }\end{array}$ \\
\hline $\begin{array}{l}\text { Tombo } \\
\text { Reso }\end{array}$ & $\begin{array}{l}\text { Jagung } \\
\text { dan sagu }\end{array}$ & $\begin{array}{l}\text { Gethuk, } \\
\text { Rebusan }\end{array}$ & Ya & Tidak & Tidak & $\mathrm{Ya}$ & Tidak & Tidak & $\begin{array}{l}\text { Ya, getah } \\
\text { umbi }\end{array}$ \\
\hline Jebubuk & $\begin{array}{l}\text { Jagung } \\
\text { dan sagu }\end{array}$ & $\begin{array}{l}\text { Gethuk, } \\
\text { Rebusan }\end{array}$ & $\mathrm{Ya}$ & $\mathrm{Ya}$ & Tidak & $\mathrm{Ya}$ & Tidak & Tidak & $\begin{array}{l}\text { Ya, getah } \\
\text { umbi }\end{array}$ \\
\hline
\end{tabular}

Tabel 3 Nilai kekerapan ditemukannya spesies Dioscorea di Hutan Wonosadi, Gunung Kidul, Yogyakarta

\begin{tabular}{llcc}
\hline No. & \multicolumn{1}{c}{ Nama spesies Dioscorea } & Nama lokal & $\begin{array}{c}\text { Nilai kekerapan } \\
(0-1)\end{array}$ \\
\hline 1. & Dioscorea esculenta (Lour.) Burg & Gembili & 0,92 \\
2. & Dioscorea alata L. & Uwi & 0,81 \\
3. & Dioscorea hispida Dennst. & Gadung & 0,75 \\
4. & Dioscorea bulbifera L. & Gembolo & 0,45 \\
5. & Dioscorea pentaphylla L. & Tomboreso atau Huwi buah & 0,21 \\
6. & Dioscorea numularia Lamk. & Jebubuk & 0,14 \\
\hline
\end{tabular}

asthma, dalam ramuan bahan alam dari Costus specious, Dioscorea bulbifera, Dioscorea pentaphylla, Urginea indica, and Ampelocissus latifolia (Choudhary et al. 2008). Bahkan menurut Kala (2009) di masyarakat Aborigin umbi D. bulbifera merupakan makanan penyegar (famine food).

Umbi tomboreso dikenal oleh masyarakat di sekitar hutan Wonosadi, Gunung Kidul namun jarang dimanfaatkan umbinya, sehingga hidupnya menjadi meliar di hutan, dan kebanyakan dikonsumsi oleh hewan liar seperti babi hutan dan kerabat pemakan umbi yang lainnya (Achmady \& Schneider 1995; Maneenoon et al. 2008). Umbi D. pentaphylla merupakan satu-satunya umbi anggota Dioscorea yang digunakan dalam pengobatan invigorator dan rheumatic secara cekokan (decoction) oral ( $\mathrm{Ji}$ et al. 2004). Umbi tomboreso bersama dengan gembolo menjadi ramuan obat untuk keluhan pernafasan (Choudhary et al. 2008).

Kearifan Budaya yang Mendukung Pelestarian Tanaman Dioscorea spp..Keberadaan tanaman Dioscorea spp. di Yogyakarta sebagian besar menempati wilayah ekosistem karst, di Kabupaten Gunung Kidul. Di dusun dan desa yang terletak di wilayah karst menanam tanaman Dioscorea spp. dipanjatkan (dibelitkan) di pagar tanaman atau sebagai tanaman sela. Umbi tanaman dapat dibiarkan di dalam tanah atau dipanen. Panen dilakukan di musim kemarau, saat musim kering (paceklik). Umbi yang digodok ataupun dibumbui dapat sebagai makanan selingan yang mengenyangkan. Tanaman uwi dengan tanaman inang belitan lamtoro memiliki hasil umbi yang paling baik, karena terjadi goyangan tajuk tanaman lamtoro yang mengikut sertakan tajuk tanaman Dioscorea spp. (Wawancara penduduk). Generalisasi dari pernyataan masyarakat tersebut adalah tanaman inang yang tajuknya tidak terlalu tinggi dan mudah bergerak oleh angin dapat menjadi inang panjatan tanaman Dioscorea spp. yang baik.

Berdasarkan kekerapan ditemukannya Dioscorea spp. di wilayah penelitian termasuk di sekitar dan di Hutan Wonosadi Yogyakarta diketahui bahwa setiap spesies memiliki nilai kekerapan atau keberadaan tertentu (Tabel 3). 
Pada Tabel 3 terlihat bahwa tanaman gembili adalah yang paling kerap dijumpai di pemukiman wilayah karst Yogyakarta, tanaman tersebut memiliki kemampuan hidup besar, demikian pula disukai oleh masyarakat untuk makanan selingan, sehingga penduduk kontinyu untuk menanam kembali atas dasar kebutuhannya untuk makanan selingan. Tanaman ini tidak memerlukan inang pembelit spesifik, dan jarang diserang hama dan penyakit, tetapi pada kesuburan tanah yang berbeda menunjukkan ukuran hasil umbi yang berbeda (Purnomo 2009). Umur tanaman 7-8 bulan, berbunga antara bulan April-Mei yaitu akhir masa vegetatif. Tanaman ini umbinya memiliki variasi warna daging, yaitu putih, putih kekuningan, dan ungu muda (senggani) (Purnomo et al. 2008). Umbi gembili selalu dijumpai di pasar tradisional di Gunung Kidul dan Bantul, Yogyakarta.

Tanaman uwi ditanam oleh masyarakat di dekat rumah, umbi tanaman ini disukai untuk makanan selingan. Tanaman uwi mudah tumbuh, dan memerlukan inang belitan yang spesifik. Masyarakat lebih memilih tanaman lamtoro (Lechaena glauca L.) atau lanjaran dari bambu. Pemupukan dengan kompos sampah dedaunan cocok untuk pertumbuhan dan perkembangan tanaman, terdapat hama penggerek daun dan umbi, penyakit daun berbintik-bintik hitam kemudian mengering sering ditemukan pada tanaman ini. Umur tanaman 6-7 bulan, berbunga antara bulan Maret-April menjelang akhir masa vegetatif. Spesies ini memiliki variasi yang besar dalam hal bentuk dan warna umbi,

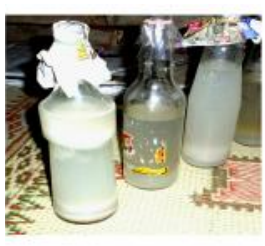

1

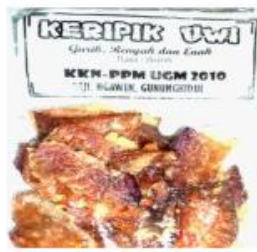

4

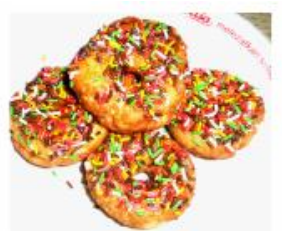

2

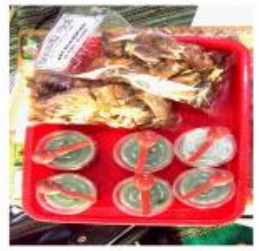

5

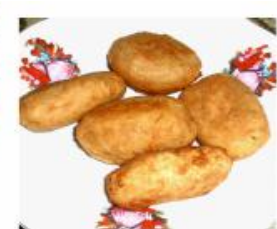

3

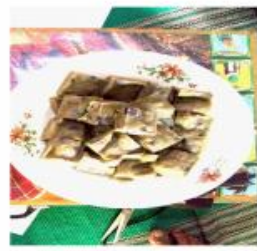

Gambar 1 Makanan olahan berbahan dasar umbi tanaman uwi yang telah dibuat oleh masayarakat di sekitar Hutan Wonosadi oleh KKN-UGM

Keterangan: 1) Nata de Uwi; 2) Donat; 3) Cemplon (KKN-UGM periode Mei-Juni 2010); 4) Kripik uwi; puding uwi; 5 dan 6) Bolu uwi dengan kemasan berbeda-beda produk KKN-UGM periode Juli-Agustus 2010 (Dokumen pribadi 2010). misal uwi beras, legi, putih, ulo, luyung putih, luyung senggani, luyung kuning, kuning, butun, bangkulit, ungu, dan senggani (Purnomo et al. 2008). Keragaman yang demikian tersebut menyebabkan lestarinya keberadaan spesies ini di alam, karena banyak orang memiliki pilihan berbeda untuk menanam tanaman uwi untuk kebutuhan tertentu. Umbi uwi juga sering ditemukan di pasar tradisional, uwi ungu banyak diperjual-belikan oleh masyarakat. Umbi uwi baik untuk diet penderita diabetes karena banyak mengandung amilopektin (Panneerselvam \& Abdul Jaleel 2008; Ji et al. 2004).

Di pemukiman sekitar hutan Wonosadi Gunung Kidul, masyarakat telah mampu mengenali tanaman Dioscorea spp., serta membuat berbagai makanan olehan berbahan dasar tepung umbi tanaman uwi. Inovasi utama Mahasiswa Kuliah Kerja Nyata UGM tahun 2010 (KKN-UGM) adalah pembuatan tepung dari umbi tanaman uwi, dari tepung tersebut produk makanan antara lain kue bolu uwi, puding uwi, dan kripik dapat disajikan dalam pertemuan warga desa. Berbagai jenis makanan olahan dari tepung uwi dapat diperiksa pada Gambar 1. Inovasi oleh mahasiswa KKN-UGM dalam pembuatan Nata de Uwi menghasilkan produk yang warnanya kurang jernih, sehingga memerlukan inovasi teknologi pangan dan gizi yang intensif untuk mendapatkan produk Nata De Uwi. Jenis pangan olahan langsung seperti rebusan umbi dengan bumbu santan kelapa dan gethuk $u w i$, perlu mendapat pengarahan tentang komposisi bumbu dan pengolahan yang sehat.

Tanaman gadung ditanam oleh masyarakat di pagarpagar pembatas kepemilikan pemukiman atau dibudidayakan secara lokal, karena umbi tanaman ini sudah dikenal sebagai bahan dasar pembuatan ceriping gadung. Tetapi, karena tanaman ini memiliki daya tumbuh yang besar, dapat ditemukan secara liar di kebun-kebun. Tanaman gadung tidak memerlukan perawatan yang khusus, hanya memerlukan pupuk dari kompos seresah daun atau pupuk kandang. Umbi gadung beracun dengan adanya kandungan senyawa setara asam sianida ( $\mathrm{HCN})$, yang mudah dilarutkan dalam air mengalir (Bhandari \& Kawabata 2005).

Gembili, uwi, dan gadung sering diperjual-belikan di pasar tradisional untuk upacara adat (sesaji), dalam konsep tukon pasar atau jajan pasar. Tukon pasar adalah bentuk sesaji oleh masyarakat yang berupa hasil bumi, untuk tatacara dan upacara tradisional pedesaan di Yogyakarta. Masyarakat di desa pelosok, memanfaatkan umbi tanaman 
untuk bertahan pada saat musim paceklik, yaitu waktu sela antara musim tanam dan musim panen tanaman utama (pokok). Tanaman pokok di Gunung Kidul adalah ketela pohon, jagung, dan sebagian padi gogo. Pada musim paceklik, sebagian besar masyarakat menjadi peternak atau tenaga buruh di daerah sekitarnya, karena musim kering di wilayah ini sangat berpengaruh bagi pertanian. Hutan Wonosadi pada tingkat sekarang hanya dapat mencukupi kebutuhan air rumah tangga, dan belum dapat menjadi sumber air pertanian. Dalam kebijakan pengelolaan sumber daya hayati yang berkelanjutan, maka pola kearifan lokal masyarakat terhadap sumber daya nabati dapat menjadi wahana pelestarian plasma nutfah (sumber daya genetik) tanaman (Suriaatmadja 1997). Dalam penelitian ini adalah untuk tanaman uwi-uwian (Dioscorea spp.).

Tanaman gembolo, tomboreso, dan jebubuk pada umumnya ditemukan tumbuh dalam bentuk liar (wildy type) karena tanaman ini jarang dimanfaatkan oleh masyarakat, karena persaingan dengan tanaman budidaya lain yang lebih menguntungkan. Ketiga spesies tersebut hanya menempati habitat tertentu di karst Gunung Kidul, Yogyakarta, khususnya di hutan Wonosadi.

\section{SIMPULAN}

Berdasarkan data yang diperoleh dapat disimpulkan bahwa desa-desa di sekitar hutan Wonosadi teridentifikasi spesies gembili (D. esculenta (Lour.) Burk.), uwi (D. alata L.), and gadung (D. hispida dennst.) sebagai tanaman budidaya, dan Tomboreso (D. pentaphylla L.), gembolo (D. bulbifera L.), dan jebubuk (D. numularia Lamk.) sebagai spesies liar di hutan. Masyarakat lebih mengkonsumsi umbi gembili dan uwi daripada gembolo dan jenis lainnya sebagai pengganti beras di musim kering. Kearifan budaya lokal masyarakat di sekitar hutan Wonosadi hubungannya dengan pelestarian Dioscorea spp. berkaitan dengan masih adanya minat masyarakat untuk mengkonsumsi hasil umbi Dioscorea spp. dengan diversifikasi pangan berbasis karbohidrat, tanaman Dioscorea spp. terutama tanaman uwi dijadikan pengisi lahan tidur atau sebagai tanaman sela, umbi tanaman sering digunakan untuk sesaji dalam konsep tukon pasar atau jajan pasar dalam upacara adat masyarakat di sekitar hutan, umbi tanaman uwi dan gembili dapat menjadi sumber pangan alternatif untuk ketahanan pangan di musim paceklik, masyarakat memanfaatkan umbi Dioscorea spp. selain sebagai sumber karbohidrat untuk pangan olahan juga dimanfaatkan untuk insektisida alamiah bagi padi dan jagung, diet penderita kencing manis, serta pengobatan awal diare dengan memakan mentah khususnya umbi uwi ungu.

\section{UCAPAN TERIMA KASIH}

Ucapan terima kasih disampaikan kepada Lembaga Penelitian dan Pengabdian Pada Masyarakat (LPPM-UGM) melalui Proyek I'MHERE Fakultas Biologi UGM yang telah memberi dana penelitian dengan nomor kontrak: UGM/BI/ 1157/I/ 05/04. April 6 2010. Bupati Gunung Kidul yang telah memberi ijin penelitian di wilayah Hutan Wonosadi dan sekitarnya. Serta Ibu Sulatri Kapala Desa Beji, Ngawen, Gunung Kidul, Yogyakarta yang telah memandu survei wawancara.

\section{DAFTAR PUSTAKA}

Achmady, L \& Schneider, J. 1995. Tuber crop in irian jaya: diversity and their need for conservation. In J. schenider (ed.). Indigenous knowledge in conservation of crops genetic resources. Proceeding of an International Workshop held in Cisarua, Bogor, Indonesia. Bogor, January 30-February 3, 1995.

Anderson, P.J. 1998. Using ecological and economic information to determine sustainable harvest levels of a plant population. Methods for Development and Conservation of Forest Products for local communities. CIFOR, IUCN.

Ariesta, K. 2004. Umbi-Umbian yang Berjasa yang Terlupa. Simpul Pangan Jogjakarta. Yayasan KEHATI.

Arnold, J.E.M \& Perez, M.R. 1998. The role of non-timber forest products in conservation and development. incomes from the forest. Methods for Development and Conservation of Forest Products for local communities. CIFOR, IUCN.

Backer C.A \& Bakhuizen v.d. Brink R.C. 1968. Flora of Java. Vol. III. N.V.P. Noordhoff, Groningen, The Netherlands.

Bapeda-Pacitan. 2005. Perencanaan Pengembangan Tanaman Kapas dan Tumbuhan Potensial Lainnya di Kabupaten Pacitan. Badan Perencanaan dan Pembangunan Daerah Kabupaten Pacitan, Jawa Timur. BAPEDA Pacitan, Jawa Timur dan Fakultas Biologi $U G M$.

Bhandari, M.R \& Kawabata, J. 2005. Bitterness and toxicity in wild yam (Dioscorea spp.) tubers of nepal. Plant Foods Hum Nutr 60: 129-135

Bimantoro, R. 1981. Uwi (Dioscorea spp.) Bahan pangan non beras yang belum diolah. Bogor: Buletin Kebun Raya 5(1).

Bressan, E., Veasey, E.A., Peroni, N., Felipim, A., Pacheco, K.M \& Santos. 2007. Collecting yam (Dioscorea spp.) 
and sweet potato (ipomoea batatas) germplasm in traditional agriculture small-holdings in the Vale do Ribeira, Sao Paulo, Brazil. Published in Issue 144: 8-13.

Choudhary, K., Singh, M \& Pillai, U. 2008. Ethnobotanical survey of rajasthan-an update. Ame-Eurasian J Bot 1(2): $38-45$.

Cotton. 1995. Ethnobotany. Principles and Applications. New York: John Willey \& Sons.

de Jong, W \& Utama, R. 1998. Turning ideas into action: Planning in non-timber forest products development. In E. Whollenberg and A. Ingles (eds). Income from the Forest Method for the Development and Conservation Of Forest Products for Local Communities. CIFOR and IUCN, Bogor, Indonesia. 43-55.

Frankel, O.H., Brown, A.H.D \& Burdon, J.J. 1995. The Conservation of Plant Biodiversity. Cambridge: Cambridge University Press.

Ji, H., Shengji, P \& Chunlin L. 2004. An ethnobotanical study of medicinal plants used by the lisu people in Nujiang, Northwest Yunnan, China. Econ Bot 58(Suppl): 253-264.

Kala, C.P. 2009. Aboriginal uses and management of ethnobotanical species indeciduous forests of Chhattisgarh state in India. Journal of Ethnobiology and Ethnomedicine 5: 20.

Maneenoon, K., Sirirugsa, P \& Sridith, K. 2008. Ethnobotany of Dioscorea L. (Dioscoreaceae), a major food plant of the Sakai tribe at Banthad range, peninsular Thailand. Ethnobot Res App 6: 385-394.

Martin, G.J. 1995. Ethnobotany: A People and Plant Conservation Manual. London: Chapman \& Hall.

Olayemi, J.O \& Ajaiyeoba, E.O. 2007. Anti-inflammatory studies of yam (Dioscorea esculenta) extract on wistar rats. Afr J Biotecnol 6(16): 1913-1915.

Panneerselvam, R. \& Abdul Jaleel, C., 2008. Starch and sugar conversion in Dioscorea esculenta tubers and Curcuma longa rhizomes during storage. Caspian $J$ Env Sci 6(2):151-160.

Purnomo. 2009. Studi etnobotani pekarangan sebagai sumber pangan di desa Sendangsari, Pajangan, Bantul, Yogyakarta. Prosiding Seminar Nasional Etnobotani IV. Keanekaragaman Hayati, Budaya dan Ilmu Pengetahuan. LIPI-Perhimpinan Masyarakat Etnobiologi-MAB UNESCO Indonesia.
Purnomo, Susandarini, R. \& Anggraeni, V.D.M. 2008. Keragaman dioscorea spp. di kabupaten Bantul dan Sleman di Daerah Istimewa Yogyakarta dan kekerabatannya berdasarkan morfologi organ vegetatif. Prosiding Seminar Nasional Biodiversitas. Surabaya: UNAIR.

Rifai, M.A. 1998. Pemasakinian Etnobotani Indonesia: Suatu Keharusan Demi Peningkatan Upaya Pemanfaatan, Pengembangan, dan Penguasaannya. Seminar Nasional Etnobotani III, Denpasar, 5-6 Mei 1998.

Sastrapradja, S. \& Rifai, M.A. 1989. Mengenal Sumber Pangan Nabati dan Plasma Nutfahnya. Bogor: Puslitbang Bioteknologi-LIPI.

Sastrapradja, S., Soejipto, N.W., Danimihardja, S \& Soejono R. 1977. Ubi-ubian. Bogor: Lembaga Biologi NasionalLIPI LBN 7, SDE 40, Proyek Sumber Daya Ekonomi.

Soeriaatmadja. 1997. Kebijakan dan strategi pengelolaan keanekaan hayati indonesia. Seminar Nasional Biologi $X V$. Perhimpunan Biologi Indonesia Cabang Lampung, Bandar Lampung.

Terauchi, R., Terachi T \& Tsunewaki, K. 1991. Intraspecific variation of chloroplast DNA in Dioscorea bulbifera $L$. Theor Appl Genet 81: 461-470.

Tjitrosoepomo, G. 1980. Klasifikasi Tumbuhan Berdasarkan Konteks Budaya Jawa. Yogyakarta: Biologi UGM.

Ukpabi, U.J. 2010. Farmstead bread making potential of lesser yam (Dioscorea esculenta) flour in Nigeria. AJCS 4(2): 68-73.

Waluyo E.B, Keim A.P \& Justina M.S. 2007. Kajian Etnotaksonomi Pandanus conoides Lamarck Untuk Menjembatani Pengetahuan Lokal dan Ilmiah. Berita Biologi LIPI 8(5).

Waluyo, E.B. 2009. Etnobotani: Memfasilitasi Penghayatan, Pemutakiran Pengetahuan, dan Kearifan Lokal Dengan Menggunakan Prinsip-Prinsip Dasar Ilmu Pengetahuan. Prosiding Seminar Nasional Etnobotani IV. (Makalah utama). Keanekaragaman Hayati, Budaya dan Ilmu Pengetahuan. LIPI-Perhimpinan Masyarakat Etnobiologi-MAB UNESCO Indonesia.

Waluyo. E.B. 2004. Pengumpulan Data Etnobotani. Dalam Rugayah, Widjaja, dan Praptiwi. Pedoman Pengumpulan Data Keragaman Flora. Bidang Botani, Pusat Penelitian Biologi, Lembaga Ilmu Pengetahuan Indonesia. 